\title{
人間による翻訳文と機械翻訳文の語菓的差異の計量分析
}

\author{
吉見毅 彦
}

本稿では, ニュース記事から無作為抽出した英文を英日機械翻訳システムで翻訳した 結果と，これらの英文を人間が翻訳した結果を照らし合わせ，両者の間にどのような 違いがあるのかを計量的に分析した. その結果, 次のような量的な傾向があることが 明らかになった。(1) 人間による翻訳に比べ, システムによる翻訳では, 英文一文が 複数の訳文に分割されにくい傾向が見られる。(2) システムによる翻訳と人間による 翻訳の間で訳文の長さの分布に統計的有意差が認められる。 (3) 用言の連用形と連体 形の分布に有意差が認められ，システムによる翻訳のほうが人間による翻訳よりも複 雑な構造をした文が多いことが示唆される。(4) 体言と用言の分布には有意差は認め られない.

さらに，動詞と名詞に関して比較検討を行ない，システムによる翻訳を人間による翻 訳に近づけるために解決すべき課題をいくつか指摘した.

キーワード： 機械翻訳, 人間による翻訳, 語彙的差異, 比較分析, 計量分析

\section{Quantitative Analysis of Morpholexical Difference between Human-Translated and Machine-Translated Sentences}

\section{TAKEHIKO YOSHIMI ${ }^{\dagger}$}

This paper carries out a quantitative analysis of morpholexical difference between machine-translated Japanese sentences and human-translated ones, both of which are obtained from English sentences selected randomly from news articles. The analysis gives the following results. (1) A tendency to translate one English sentence into multiple Japanese sentences is less observed in machine translation than in human translation. (2) Significant difference exists in the distribution of the sentence length between machine- and human-translated sentences. (3) Significant difference in the distribution of the adverbial form and the attributive form of verbs and adjectives intimates that machine-translated sentences have more complex syntactic structure than human-translated ones do. (4) No significant difference exists in the distribution between verbs, adjectives and nouns.

A further investigation on verbs and nouns reveals what kind of technical challenges must be solved to improve the quality of machine translation up to the extent of human translation.

KeyWords: Machine Translation, Human Translation, Morpholexical Difference, Comparative Analysis, Quantitative Analysis

\footnotetext{
†龍谷大学理工学部情報メディア学科, Department of Media Informatics, Faculty of Science and Technology, Ryukoku University
} 


\section{1 はじめに}

1980 年代に市販され始めた機械翻訳システムはその後改良が重ねられ，システムの翻訳品 質は確実に向上してきている。しかし，現状のシステムには解決すべき課題が数多く残されて おり，高品質の翻訳が可能なシステムは未だ実現されていない.

翻訳品質を高めるためにシステムを評価改良していく方法としては，(1) システムの新バー ジョンによる訳文と旧バージョンによる訳文との比較や，異なるシステム間での比較によって 行なう方法 (Niessen et al. 2000; Darwin 2001) と，(2) システムによる訳文と人間による訳文 を比較することによって行なう方法 (菅谷他 2001; Papineni et al. 2002) がある. 前者の方法で は,システムによる翻訳 (以降，MT 訳と呼ぶ) と人間による翻訳 (人間訳) を比較することに よって初めて明らかになる課題が見逃されてしまう恐れがある。これに対して，後者の方法で は，MT 訳と人間訳の間にどのような違いがあるのかを発見し，その違いを埋めていくために 取り組むべき課題を明らかにすることができる.

このように，MT 訳と人間訳の比較によるシステムの評価改良は有用な方法である。しかし ながら, MT 訳と人間訳の違いを明らかにするために両者の比較分析を計量的に行なった研究 は，従来あまり見られない.

ところで，人間によって書かれた文章間の比較分析は，文体論研究の分野において以前から 行なわれてきている (山口 1979). 文体論研究の目的は, 比較対象の文章の個別的あるいは類型 的特徵を明らかにすることにある，文体論研究は，文章に対する直観的な印象を重視する立場 と, 文章が持つ客観的なデー夕 (文長や品詞比率など) を主に扱う計量的立場 (波多野 1965)に 分けることができる.また，別の観点からは，言語表現の特徴を作家の性格や世界観に結び付 けて扱う心理学的文体論と, 言語表現の特徵を記述するに留める語学的文体論 (樺島 1963)に分 けられる. 計量的・語学的文体論に分類される研究のうち, 同一情報源に基づく内容を伝える 文章を比較対象とした研究として，文献 (堀川 1979; 蓮見 1991) などがある. 堀川は, 四コマ 漫画の内容を説明する文章を童話作家, 小説家, 学者に書いてもらい, それらの違いを分析し ている. 蓮見は, 古典の源氏物語を複数の翻訳者が現代語に翻訳した文章において, 文数, 文 長, 品詞比率などを比較分析している.

本研究では, 英日機械翻訳システムの翻訳品質の向上を目指し, その第一歩として, 英文 ニュース記事に対する人間訳と MT 訳を比較し, それらの違いを計量的に分析する. 人間訳と MT 訳の違いは多岐にわたるため様々な観点から分析を行なう必要があるが, 本稿では, 英文 一文に対する訳文の数, 訳文の長さ, 文節レベルの現象について量的な傾向を明らかにする.

なお, 特に MT 訳には誤訳の問題があるが, 本研究は, 訳文の意味内容ではなく訳文の表 現形式について分析するものである。すなわち, 翻訳の評価尺度として忠実度と理解容易性 (Nagao et al. 1985) を考えた場合，後者について，MT 訳の分かりにくさ，不自然さの原因が どこにあるのかを人間訳と MT 訳を比較することによって明らかにしていくことが本研究の目 
的である。

以下， 2 節で人間訳と MT 訳の比較分析方法について述べ， 3 節で分析結果を示し，考察を 加える．最後に 4 節で今回の比較分析で明らかになった点をまとめる.

\section{2 調査方法}

\section{1 調査対象とした標本}

コーパスとして Bilingual Net News ${ }^{1}$ の英文ニュース記事を使用し，2001 年 5 月 26 日から 2002 年 1 月 15 日までの記事を構成する英文 5592 文を母集団とした。これらの英文にはあらか じめ人間訳が与えられている。

この母集団から乱数によって 500 文を単純無作為抽出した.この 500 文を市販されている代 表的な機械翻訳システムの一つで翻訳し，入力文全体を覆う構文構造が得られなかった文と， 一文の認識に失敗した文 ${ }^{2}$, 合わせて 24 文を除いた 476 文を標本とした.

これらの英文 476 文の文長の平均值は，11.5 であり，標準偏差は 6.2 であった，文長の計測 は, 冠詞や前置詞などの機能語と, ピリオドや引用符などの記号を除き, 内容語の数で行なった.

また，訳文の数を地の文の句点の数で数えた場合，英文 476 文に対する訳文数は，人間訳で は 559 文であり, MT 訳では 519 文であった。

\section{2 形態素解析と文節解析}

人間訳と MT 訳の.各文に対して, 形態素解析と文節解析を行なった。これらの処理には, 形 態素解析システム茶筅 ${ }^{3}$ と係り受け解析システム南瓜 4 をデフォルトの状態で利用した.

\section{3 解析結果の変更}

茶笔と南瓜による解析結果に対して, 必要な変更を人手で加えた. 品詞夕グ付け誤りの修正 以外の主な変更点は次の通りである，なお，変更前の文節区切りを記号‘’で，変更後の文節区 切りを記号‘/で表わす。 また，茶笔での品詞タグを二重引用符で括って示す. “未知語”は名詞に変更する。

南瓜による解析では “名詞-非自立”が自立語として扱われている場合がある(「難色 を|示した|ため」など)が，これを付属語とみなす (「難色を/示したため」).

1 http://www.bnn-japan.com/

2 例えば, 'Bush backs the more comprehensive ban sponsored by Rep. David Weldon (R) of Florida.' という文 は, 'Rep.'のところで一つの文が完結し，'David’のところから新たな文が始まると認識されてしまう。

3 http://chasen.aist-nara.ac.jp/chasen/

4 http://cl.aist-nara.ac.jp/ taku-ku/software/cabocha/ 
（4）「「た」,「である」,「です」が “名詞-形容動詞語幹”と結合しているとき，全体を形容 動詞とする。

（5）「だ」,「である」,「です」が “名詞-形容動詞語幹” 以外の名詞と結合して述語を構成 しているとき，これらを判定詞とする．

（6）「に|よる」,「に|基づく」などは, 原則として, 全体を助詞とみなす.

（7）“記号”は，原則として，“接頭詞”または付属語と同様に扱う。

\section{4 調查分析項目}

まず，概略的な調査として，英文一文に対する訳文の数，訳文の長さ，訳文に含まれる連体 修飾節の数について人間訳と MT 訳を比較する。これらの調査は, 人間訳と MT 訳の複雑さに 違いがあるかを明らかにするためのものである。

次に，体言と用言の分布に人間訳と MT 訳で違いがあるかを調査する。この調査の目的は, 名詞を中心として展開していく英語の構造が人間訳と MT 訳でそれぞれどのように訳されてい るかを明らかにすることにある。なお, 本稿では, 動詞, 形容詞, 形容動詞の他に判定詞も用 言とみなす。

さらに, 動詞, 名詞, 代名詞について若干詳細な比較分析を行なう。これらの品詞に着目し たのは, 動詞と名詞 (代名詞) は, 出現比率が高く, これらを適切に処理することが特に重要な 課題になっているからである.

\section{3 結果と考察}

\section{1 英文一文に対する訳文数}

自然な翻訳では，英文一文が訳文一文に対応しているとは限らず，複数の文に分けて訳され ることも少なくない.そこで，まず，人間訳と MT 訳それぞれにおいて訳文数が $n$ 文である英 文の数を $n$ 毎に集計した. その結果を表 1 に示す. 表 1 において, 上段が頻度, 下段が比率で ある。

表 1 訳文数が $n$ 文である英文の数

\begin{tabular}{|c||r|r|r|r|}
\hline$n$ & \multicolumn{1}{|c|}{1} & \multicolumn{1}{c|}{2} & \multicolumn{1}{c|}{3} & \multicolumn{1}{c|}{4} \\
\hline \hline \multirow{2}{*}{ 人間訳 } & 403 & 64 & 8 & 1 \\
& $84.7 \%$ & $13.4 \%$ & $1.7 \%$ & $0.2 \%$ \\
\hline \multirow{2}{*}{$\mathrm{MT}$ 訳 } & 433 & 43 & 0 & 0 \\
& $91.0 \%$ & $9.0 \%$ & $0.0 \%$ & $0.0 \%$ \\
\hline
\end{tabular}


表 1 を見ると，人間訳では英文一文が三文以上に分けて訳されていることもあるのに対して， MT 訳では高々二文にしか分割されていない 5 ．また，MT 訳では，英文一文が二文に訳される ことは比較的少なく，一文に訳されることが多い. 人間訳と MT 訳における訳文数の分布の差 は, 有意水準 $5 \%$ で統計的に有意である。これらのことから, $\mathrm{MT}$ 訳には, 人間訳に比べて, 複 数の文に分割されにくい傾向があると言える.

表 1 から, 英文一文に対する訳文数の分布に人間訳と MT 訳とで差があることが分かった が,さらに詳細な分析を行なうために, 人間訳での訳文数 $n(n=1,2,3,4)$ と MT 訳での訳文 数 $m(m=1,2)$ との対応関係を調査した。 その結果を表 2 に示す.

表 2 人間訳と MT 訳の訳文数の対応

\begin{tabular}{|c||r|r|r|r|}
\hline MT 訳 $(m) \backslash$ 人間訳 $(n)$ & \multicolumn{1}{|c|}{1} & \multicolumn{1}{c|}{2} & \multicolumn{1}{c|}{3} & \multicolumn{1}{c|}{4} \\
\hline \hline \multirow{2}{*}{1} & 371 & 55 & 7 & 0 \\
& $77.9 \%$ & $11.6 \%$ & $1.5 \%$ & $0.0 \%$ \\
\hline \multirow{2}{*}{2} & 32 & 9 & 1 & 1 \\
& $6.7 \%$ & $1.9 \%$ & $0.2 \%$ & $0.2 \%$ \\
\hline
\end{tabular}

表 2 によれば, 全体的な傾向として, 人間訳と MT 訳とで訳文数が等しい場合が 380 件 $(79.8 \%)$ あり，人間訳と MT 訳とで訳文数が異なる場合が 96 件 $(20.2 \%)$ ある.

表 2 では, 英文一文が人間訳では一文に訳されているのに対して MT 訳では二文に分けて訳 されている場合が 32 件ある.この 32 件について，英文のどのような表現のところで分割され ているかを調べた. その結果を表 3 に示す.

表 3 MT 訳のみでの訳文分割箇所

\begin{tabular}{|l|r|}
\hline \multicolumn{1}{|c|}{ 分割箇所 } & \multicolumn{1}{|c|}{ 頻度 } \\
\hline \hline 従属接続詞 (名詞節) & $14(43.8 \%)$ \\
等位接続詞 & $9(28.1 \%)$ \\
従属接続詞 (副詞節) & $6(18.8 \%)$ \\
現在分詞 & $1(3.1 \%)$ \\
関係副詞 & $1(3.1 \%)$ \\
コロン & $1(3.1 \%)$ \\
\hline
\end{tabular}

表 3 を見ると, 分割が生じる表現のほとんどは, 名詞節を導く従属接続詞 ('that'など), 等 位接続詞 ('and'など), 副詞節を導く従属接続詞 ('because'など) で占められている.なお, 名 詞節を導く従属接続詞の集計には, 従属接続詞が省略されている場合も含めている.

5 MT訳での文の分割は, 機械翻訳システムが正常に動作した結果である. 2.1 節で述べたように, 入力文全体を覆う構 文構造が得られないために分割された文は標本に含まれていない。 
逆に，英文一文が人間訳では二文に分けて訳されているのに対して MT 訳では一文に訳さ れている 55 件について, 英文のどのような表現のところで分割されているかを調べた結果を表 4 に示す.

表 4 人間訳のみでの訳文分割箇所

\begin{tabular}{|l|r|}
\hline \multicolumn{1}{|c|}{ 分割箇所 } & \multicolumn{1}{|c|}{ 頻度 } \\
\hline \hline 関係代名詞 & $14(25.5 \%)$ \\
前置詞 & $10(18.2 \%)$ \\
等位接続詞 & $7(12.7 \%)$ \\
従属接続詞 (副詞節) & $7(12.7 \%)$ \\
現在分詞 & $6(10.9 \%)$ \\
従属接続詞 (名詞節) & $4(7.3 \%)$ \\
to 不定詞 & $2(3.6 \%)$ \\
関係副詞 & $2(3.6 \%)$ \\
その他 & $3(5.5 \%)$ \\
\hline
\end{tabular}

表 4 を見ると，MT 訳に見られない分割箇所として関係代名詞や前置詞が目立つ. 次の文 (H1)のように，文を関係代名詞のところで二分割し，それらの間を同一名詞の繰り返しによっ てつなぐ手法は，よく知られている英日翻訳技法の一つである (安西 1982; 近藤 1992; 亀井 1994).なお，本稿では，英文，人間訳，MT訳をそれぞれ (E1)，(H1)，(M1)のように参照す る．英文と人間訳はすべて Bilingual Net News からの引用である．記事の掲載年月日を英文の 後ろに示す。

(E1) House and Senate negotiators quickly began hammering out a final compromise, which Republicans hoped to present for Bush's signature as soon as today. [2001 年 5 月 26 日]

（H1）下院と上院の交渉者たちはすぐに最終的な妥協案を成立させることにとりかかっ た。共和党は今日にも妥協案をまとめて提出しブッシュの署名を得たいと望んで いる。

（M1） 下院，そして，上院交渉者は，迅速に最終の妥協 (共和党員がブッシュのサイン のために今日と同じくらいすぐに提示することを望んだ)を打ち出し始めた.

表 4 は，このような手法が調査対象のシステムに取り入れられていないことを示している. 関係節を伴う名詞句を機械翻訳システムにおいて適切に処理するための自動前編集手法が文献 (加藤他 1997; 佐良木 2001) などで報告されていたり，今回の調査に用いたシステムとは異なる 別の市販システムでは関係代名詞が先行詞に置き換えられることがあったりするが，人間が行 なう関係節の翻訳は，柔軟性に富み，かつ，様々な工夫がなされているため，関係節に関する 翻訳規則をより高度化していく必要がある。 
人間訳では，前置詞のところで文を単に分割するだけでなく，自然な翻訳になるように工夫 が施されている，その一つは，前置詞句が一つの完全な文になるように翻訳されている点であ る (中村 1982). 例えば次の文 (H2) では,「のものである」が補われている. また別の工夫とし て，二つの文を滑らかにつなぐために,「これは」という照応表現が補われている。

(E2) In an epic tennis match, Pete Sampras edged Andre Agassi to reach the US Open semi-finals after a dramatic confrontation in which neither legend lost a service game. [2001 年 9 月 8 日]

(H2) 叙事詩のようにすごいテニスの戦いで, ピート・サンプラスはアンドレ・アガシ に競り勝ち，全米オープン準決勝に進んだ。これは，どちらの伝説的選手もサー ビスゲームを落とさないという, 劇的な対決の末のものである.

(M2) 叙事詩のテニスの試合において，ピート・サンプラスは，劇的な直面 (伝説のい ずれもサービスゲームに負けなかった) の後で全米オープン準決勝に達するため に，アンドレ・アガシを研いだ。

\section{2 訳文の長さ}

文の長さは，文章の類型設定に関する心理学的研究 (波多野 1965) や，文章の難易度の測定 (森岡 1988), 手書き文章とワープロ書き文章の比較分析 (金他 1993) など様々な研究において, 比較尺度として用いられている。

本節では，文長を，訳文の複雑さを近似的に測るための尺度の一つとして用いる．日本語の 文の長さを測る単位としては，文字，単語，文節などが考えられるが，ここでは文節数 (自立語 数)を計測単位とする.

人間訳と MT 訳それぞれにおける文長の度数分布表を表 5 と表 6 に示す. 表 5 と表 6 の累積 比率を比べると，人間訳では文長 14 までの文が全体の $85.8 \%$ 占めるのに対して，MT 訳では $73.8 \%$ しかないことなどから，人間訳より MT 訳のほうが長い文が多いと言える. Wilcoxonの 順位和検定の結果，人間訳と MT 訳の文長の分布の間には有意水準 $5 \%$ で有意差が認められた。

文長の平均值は人間訳で $9.25, \mathrm{MT}$ 訳で 10.42 , 標準偏差は人間訳で $4.94, \mathrm{MT}$ 訳で 5.95 と, 平均值, 標準偏差とも MT 訳のほうが若干大きい.

MT 訳での文長の最頻值は階級では $11 \sim 12$ であるが, 観測值では 2 である. MT 訳での最 頻值が 2 となるのは，次の文 (M3) のように，伝達文の主節だけを独立した文として訳してい る場合が多いためである。

(E3) Hastert said both sides are trying to strike a compromise. [2001 年 7 月 28 日]

(H3) ハスタートは，両党とも妥協を試みていると語っている.

(M3) Hastert は言った. 両側は, 妥協を打とうとしていると. 
表 5 人間訳に扔ける文長の分布

\begin{tabular}{|r||r|r|r|r|}
\hline \multicolumn{1}{|c||}{ 文長 } & 度数 & \multicolumn{1}{|c|}{ 比率 } & 累積度数 & 累積比率 \\
\hline \hline $1 \sim 2$ & 47 & $8.4 \%$ & 47 & $8.4 \%$ \\
$3 \sim 4$ & 65 & $11.6 \%$ & 112 & $20.0 \%$ \\
$5 \sim 6$ & 62 & $11.1 \%$ & 174 & $31.1 \%$ \\
$7 \sim 8$ & 89 & $15.9 \%$ & 263 & $47.0 \%$ \\
$9 \sim 10$ & 82 & $14.7 \%$ & 345 & $61.7 \%$ \\
$11 \sim 12$ & 81 & $14.5 \%$ & 426 & $76.2 \%$ \\
$13 \sim 14$ & 57 & $10.2 \%$ & 483 & $86.4 \%$ \\
$15 \sim 16$ & 31 & $5.6 \%$ & 514 & $92.0 \%$ \\
$17 \sim 18$ & 22 & $3.9 \%$ & 536 & $95.9 \%$ \\
$19 \sim 20$ & 12 & $2.2 \%$ & 548 & $98.1 \%$ \\
$21 \sim 22$ & 3 & $0.5 \%$ & 551 & $98.6 \%$ \\
$23 \sim 24$ & 3 & $0.5 \%$ & 554 & $99.1 \%$ \\
$25 \sim 26$ & 4 & $0.7 \%$ & 558 & $99.8 \%$ \\
$27 \sim 28$ & 1 & $0.2 \%$ & 559 & $100.0 \%$ \\
\hline \hline
\end{tabular}

表 6 MT 訳における文長の分布

\begin{tabular}{|r||r|r|r|r|}
\hline \multicolumn{1}{|c||}{ 文長 } & 度数 & \multicolumn{1}{|c|}{ 比率 } & 累積度数 & 纍積比率 \\
\hline \hline $1 \sim 2$ & 47 & $9.0 \%$ & 47 & $9.0 \%$ \\
$3 \sim 4$ & 56 & $10.8 \%$ & 103 & $19.8 \%$ \\
$5 \sim 6$ & 60 & $11.5 \%$ & 163 & $31.3 \%$ \\
$7 \sim 8$ & 57 & $11.0 \%$ & 220 & $42.3 \%$ \\
$9 \sim 10$ & 46 & $8.9 \%$ & 266 & $51.2 \%$ \\
$11 \sim 12$ & 68 & $13.1 \%$ & 334 & $64.3 \%$ \\
$13 \sim 14$ & 51 & $9.8 \%$ & 385 & $74.1 \%$ \\
$15 \sim 16$ & 50 & $9.6 \%$ & 435 & $83.7 \%$ \\
$17 \sim 18$ & 32 & $6.2 \%$ & 467 & $89.9 \%$ \\
$19 \sim 20$ & 27 & $5.2 \%$ & 494 & $95.1 \%$ \\
$21 \sim 22$ & 11 & $2.1 \%$ & 505 & $97.2 \%$ \\
$23 \sim 24$ & 4 & $0.8 \%$ & 509 & $98.0 \%$ \\
$25 \sim 26$ & 6 & $1.2 \%$ & 515 & $99.2 \%$ \\
$27 \sim 28$ & 4 & $0.8 \%$ & 519 & $100.0 \%$ \\
\hline
\end{tabular}

\section{3 連体修飾節の数}

文の長さは文の複雑さを測る尺度の一つとなりえるが，それだけでは十分な近似ではない. 例えば次の二つの文は文長 (文節数) は等しいが，文構造としては連体修飾節を含む文 (J4') の ほうが複雑である ${ }^{6}$.

(J4)シングテルは政府所有の会社で，経営を世界規模に広げて業界大手になることを 目指している。

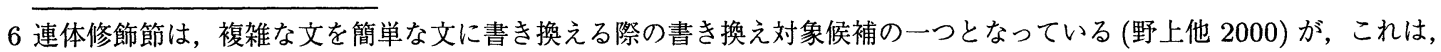
連体修飾節を含む文 $\left(\mathrm{J} 44^{\prime}\right)$ のような文が複雑になる傾向があるからであろう. 
(J4') シングテルは，経営を世界規模に広げて業界大手になることを目指している政府 所有の会社である。

文 (J4)のような文のほうが読み手の負担が軽いことに関して文献 (柳父 1979) では次のよう に述べられている。

読者は，動詞が現れたところで，だいじな意味を語ることばが分り，思考の流れ

はひと区切りつくのである．ひと区切りついた部分は一応前へ預けておいて，そ

の先へ読み進んで行ける, 文は, 全体としては長いが, 読者の頭脳には, この文

の長さは決して過重な負担とはならないのである.

意味的に一区切りつけることができるのは, 用言 (動詞, 形容詞, 形容動詞, 判定詞) の連 用形が現れるところである. 文 (J4) の場合, 判定詞「だ」の連用形「で」のところで意味的な まとまりを認識することができる，これに対して，文 (J4')における「目指している」のよjに 用言の連体形が現れるところでは，意味的な区切りをつけることができない.そこで, 人間訳 と MT 訳とで用言の連用形と連体形の分布に差があるかどうかを調べた.

茶笔の活用形の分類では, 終止形と連体形が区別されず, これらの代わりに “基本形”とい う一つのタグが与えられている。このため，“基本形”を含む文節において次の三つの条件のう ちいずれかが成り立つ場合に, “基本形”を連体形とみなし, それ以外の場合には終止形とみな すことにした。

(1) “基本形”が文節末尾の形態素である.

（2）“基本形”に“名詞-非自立”が後続する.

（3）“基本形”に“記号-読点”が後続し，その“記号-読点”が文節末尾の形態素である.

表 7 に集計結果を示す. 連用形と連体形の分布に差があるかどうかを $\chi^{2}$ 検定したところ， 有意水準 $5 \%$ で差があると認められた。

表 7 用言の連用形と連体形の分布

\begin{tabular}{|c||r|r|}
\hline 活用形 & 連用形 & 連体形 \\
\hline \hline \multirow{2}{*}{ 人間訳 } & 190 & 576 \\
& $24.8 \%$ & $75.2 \%$ \\
\hline \multirow{2}{*}{$\mathrm{MT}$ 訳 } & 146 & 626 \\
& $18.9 \%$ & $81.1 \%$ \\
\hline
\end{tabular}

連用形は人間訳でより多く，連体形は MT 訳でより多く出現する。このことから， MT 訳の ほうが人間訳よりも複雑な文構造をした文が多い可能性が示唆される. 連体形の数が, 長く複 雑な連体修飾節の数に直接結びっくわけではないが，ある程度の傾向を知ることはできる．よ り正確な傾向を把握するためには, 文中において係り先が未だ決まっていない文節数を数える 
(村田他 1999) などの構文的なレベルでの検証が必要である.

\section{4 体言と用言の分布}

英語は名詞を中心として展開していく構造であるのに対して，日本語は用言を中心として展 開していく構造である (柳父 1979). 従って, 人間による自然な翻訳では, 英語の名詞中心の構 造は, 日本語の用言中心の構造に変換されていると考えられる，他方，英語の名詞的表現を日 本語の動詞的表現に変換することは現状の機械翻訳システムでは容易ではなく，一般的な方法 は実現されていない7．このため，体言の出現比率はMT 訳のほうが高くなると予想される.

この点を確認するために, 体言 (代名詞を含む名詞) と用言 (動詞, 形容詞, 形容動詞, 判定 詞)の分布を求めた。その結果を表 8 に示す. 表 8 を見ると, 体言の比率は MT 訳のほうが若 干高いが, 統計的には人間訳と MT 訳で体言と用言の分布に有意差は認められない (有意水準 $5 \%)$.

表 8 体言と用言の分布

\begin{tabular}{|c||r|r|}
\hline & \multicolumn{1}{|c|}{ 体言 } & \multicolumn{1}{|c|}{ 周 } \\
\hline \hline \multirow{2}{*}{ 人間訳 } & 3441 & 1238 \\
& $73.5 \%$ & $26.5 \%$ \\
\hline \multirow{2}{*}{ MT 訳 } & 3513 & 1191 \\
& $74.7 \%$ & $25.3 \%$ \\
\hline
\end{tabular}

以下， 3.5 節と 3.6 節で動詞と名詞についてそれぞれ分析する.

\section{5 動詞に関する分析}

出現頻度が 5 以上の動詞の基本形の一覧を表 9 に示す。記号 (*’が付いている語は，人間訳 でも MT 訳でも頻度 5 以上で出現するものである。また，例えば「言う」と「いう」のように 記号 ‘(*)’が付いている語は, それらを異緅りとみなせば, 人間訳でも MT 訳でも頻度 5 以上で 出現する語である.

表 9 から次のような特徵が読み取れる.

（1）「なる」は人間訳にも MT 訳にも現れるが，出現頻度が人間訳では 74 と高いのに対 して, MT 訳では 12 と比較的低い.

(2)「「言う」の出現頻度が MT 訳では 51 と高いのに対して, 人間訳では 6 と低い.

(3) 人間訳では,「行 (な) う」,「受ける」,「出す」,「かける」などの機能動詞 (村木 1991) が多い.

7 この問題に取り組んだ研究として, 文献 (吉見 2001a) などがある. 
表 9 出現頻度 5 以上の動詞の一覧

\begin{tabular}{|c|c|c|c|}
\hline \multicolumn{2}{|r|}{ 人間訳 } & \multicolumn{2}{|r|}{ MT 訳 } \\
\hline 頻度 & 訳語 (基本形) & 頻度 & 訳語 (基本形) \\
\hline 74 & なる* & 51 & 言う(*) \\
\hline 55 & する* & 34 & する* \\
\hline 38 & ある* & 18 & ある* \\
\hline 32 & 述べる* & 15 & 発表する* \\
\hline 24 & 発表する* & 13 & 持つ* \\
\hline 20 & 行う* & 12 & 示す*，なる* \\
\hline 13 & 受ける & & \\
\hline 11 & いる*，語る & 11 & 拒絶する \\
\hline 10 & 求める*，見る*，開く & 10 & 獲得する, 望む \\
\hline 9 & 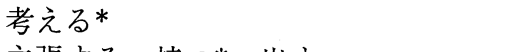 & 9 & 先導する，与える*，使う，考える* \\
\hline 8 & 主張する, 持つ*, 出す & 8 & $\begin{array}{l}\text { 予測する, 見る*, 述べる*, 行う*, } \\
\text { 分かる，思う* }\end{array}$ \\
\hline 7 & 非難する，起きる，示す* & 7 & $\begin{array}{l}\text { 報告する, カットする, 増加する*, } \\
\text { もたらす, 求める* }\end{array}$ \\
\hline 6 & $\begin{array}{l}\text { かける, みる, いう }(*), \text { 得る, 向け } \\
\text { る }\end{array}$ & 6 & $\begin{array}{l}\text { 独立する, 告発する, 確認する, 提 } \\
\text { 案する, 置く, できる, 戻る, 含む*, } \\
\text { 殺す, いる* }\end{array}$ \\
\hline 5 & $\begin{array}{l}\text { 開始する, 死亡する, 殺害する, 警告 } \\
\text { する, 調査する, 拒否する, 減少する, } \\
\text { 予定する, 実現する, 増加する*, 行 } \\
\text { なう (*), 含む*, 支払う, 思う*, な } \\
\text { す, 出る, 認める, 報じる, 与える* }\end{array}$ & 5 & $\begin{array}{l}\text { 保持する, 宣告する, 所有する, サ } \\
\text { ポートする, 支持する, 提供する, 終 } \\
\text { える, 会う, 告げる }\end{array}$ \\
\hline
\end{tabular}

\subsection{1「「する的表現と「なる」的表現}

よく知られているように，英語では行為者が対象に能動的に働きかけるという捉え方がされ る傾向が強いのに対して, 日本語では物事が自然にある状態になるという表現が好まれる (池 上 1981; 安西 1983). 上記の特徵 (1) は, このような英語と日本語の言語的慣習の違いに現状 の機械翻訳システムが対処できていないことを示唆している。例えば，次の文 (H5) では,「法 律によって政府は…提出できるようになる」という表現がなされている。これに対して，文 (M5) では，英語表現と同様に，行為者「規則」が対象「政府」に働きかけるという表現になっ ている.

(E5) Rules for such a court also give the government a freer hand to introduce evidence. [2001 年 11 月 16 日]

(H5) さらに, このような裁判所で適応される法律によって, 政府は, 証拠をより自由 に提出できるようになる。

(M5) 同じくそのような法廷のための規則は, 証拠を提出するために, 政府に更に自由 な援助を行う。 
なお，表 9 の集計では「する」が自動詞か他動詞かの区別や能動態か受動態かの区別をしてい ないが,「する」的表現と「なる」的表現の量的な違いを厳密に把握するためにはこれらの区別 を考慮する必要がある.

\subsection{2 'say' の訳し分け}

MT 訳で「言う」と訳されているのは'say'である.「言う」の出現頻度が人間訳で低いのは, 'say'が「述べる」や「語る」,「発表する」などに訳し分けられているためである. 調査対象が ニュース記事であるため記者会見での発言が多いが，このような発言では，'say'を「言う」と 訳すより,「述べる」などと訳したほうが適切であることによるものであろう.

\subsection{3 機能動詞表現}

機能動詞表現は，例えば「注目を集める」のように，表現全体の実質的意味のほとんどを担 う名詞と, 文法的な機能を果たすだけで動詞本来の意味を持たない動詞とから構成される表現 である (村木 1991).

機能動詞は同一表現の繰り返しを避けたい場合や受動態にすると不自然になる場合などに用 いられ，これによって表現の豊富さや自然さがもたらされる，例えば，次の文 (H6) で用いられ れている機能動詞表現「治療を受ける」と, 文 (M6) で用いられれている受動態「治療される」 を比べると，後者には不自然さが感じられる.

(E6) Thousands of postal and Capitol workers were being treated with antibiotics as a precaution. [2001 年 10 月 19 日]

（H6）数千の郵便や議事堂の労働者は，予防として抗生物質での治療を受けている.

(M6) 何千もの郵便の, そして, 国会議事堂労働者は, 事前対策として抗生物質で治療 されつつあった.

この点を確認するために, ウェブ検索エンジン Google と AltaVista を用いて, ウェブ文書に おける「治療され」の出現頻度と「治療を受け」の出現頻度を比較したところ, 前者の出現頻度 が Google で 1210, AltaVista で 3859 であるのに対して，後者の出現頻度は Google で 21900， AltaVista で 34374 であった 8 .「治療を受ける」において，助詞「を」は「も」，「は」,「さえ」 など他の助詞との交替が可能であり,さらに，名詞と機能動詞の間に他の語句の挿入が可能で あるが，このような交替や抻入が生じた表現は検索の対象としていないので，これらを考慮し た場合の出現頻度はさらに高くなる。このことから,「治療される」は「治療を受ける」に比べ て用いられにくい表現であると言えそうである。

8 これは 2002 年 8 月 23 日の検索結果である. 


\section{6 名詞に関する分析}

表 10 出現頻度 5 以上の名詞の一覧

\begin{tabular}{|c|c|c|c|}
\hline \multicolumn{2}{|r|}{ 人間訳 } & \multicolumn{2}{|r|}{ MT 訳 } \\
\hline 頻度 & 訳語 & 頻度 & 訳語 \\
\hline & & 69 & 彼* \\
\hline & & 65 & それら \\
\hline 21 & アメリカ $(*)$ & 53 & 米国* \\
\hline 16 & 彼* & 40 & それ* \\
\hline 15 & ブッシュ大統領* & 17 & 他*, 状態, 政府*, 会社 \\
\hline 14 & これ & 16 & イスラエル* \\
\hline 13 & 政府* & 14 & 攻撃，人々* \\
\hline 11 & 予定*, 大統領 & 11 & $\begin{array}{l}\text { アフガニスタン*, 最初*, 日本*, パ } \\
\text { レスチナ }\end{array}$ \\
\hline 10 & それ* & 10 & 2 人*, 取扱い, 多く \\
\hline 9 & $\begin{array}{l}\text { アフガニスタン*, 可能性, ロシア*, } \\
\text { 女性*, 州, 今回 }\end{array}$ & 9 & ホーム, ブッシュ, 予定* \\
\hline 8 & $\begin{array}{l}\text { 米国*, } 9 \text { 月 } 11 \text { 日，日本*, 議会*, } \\
\text { 人々*, 以下, 他* }\end{array}$ & 8 & $\begin{array}{l}\text { ブッシュ大統領*, 近く, ロシア*, ジョ } \\
\text { ブ, 闘士, 最近*, パキスタン*, 英国 } \\
(*), \text { 全て, 会議 }\end{array}$ \\
\hline 7 & $\begin{array}{l}\text { 選挙*, ワシントン*, 従業員, パレ } \\
\text { スチナ人, 調査, ニューグ, } \\
\text { 人*, イギリス }(*) \text {, 先週*, イスラエ } \\
\text { ル*, 人* }\end{array}$ & 7 & $\begin{array}{l}\text { リーダ, 何千, レイオフ, 総裁, 都市*, } \\
\text { ワシントン*, 先週*, ニューヨーク*, } \\
\text { 5., 6., あなた }\end{array}$ \\
\hline 6 & $\begin{array}{l}\text { 同社, 一環, 最近*, 家, 国, 上院, } \\
\text { 今, 裁判所, 最初*, その他, 本社, } \\
\text { 都市* }\end{array}$ & 6 & 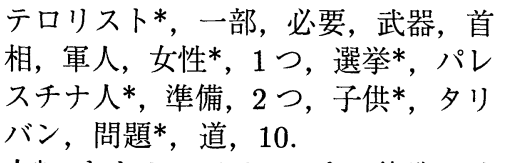 \\
\hline 5 & $\begin{array}{l}\text { アラファト議長, 北アイルランド, 彼 } \\
\text { ら, 人物, 東芝, 買収, } 1 \text { 人, ホワイ } \\
\text { トハウス, テロリスト*, 報道, 映画, } \\
\text { 第 } 6 \text { 位, 取引, 国連, 現在, 問題*, } \\
\text { パキスタン*, その後, 爆弾, 家庭, } \\
\text { 子供*, 罪 }\end{array}$ & 5 & $\begin{array}{l}\text { 人*, ヤセル・アラファト, 停戦, イ } \\
\text { スラム教, 結果, 連邦, 歴史, イラ } \\
\text { ン, ケース, 国家, 人間, メーカー, } \\
4 \text { つ, 時間, 前, 戦い, 暴力, 議会*, } \\
\text { 日曜日, 新聞, 今年, 昨年, 有罪, ア } \\
\text { ナリスト, 軍隊 }\end{array}$ \\
\hline
\end{tabular}

出現頻度が 5 以上の名詞の一覧を表 10 に示す．表 10 から次のような特徴があることが読み 取れる。

（1）人間訳に比べて MT 訳での出現頻度が高い (頻度差が 10 以上の) 名詞は,「彼」(頻度 差：53),「それら」(65),「それ」(30),「米国」(24),「状態」(15),「会社」(14), 「攻撃」 (11),「パレスチナ」(11),「取扱い」(10)であるが, 特に代名詞の出現頻度差が大きい.

逆に, MT 訳に比べて人間訳での出現頻度が高い名詞は,「これ」(頻度差：12)である.

まず，代名詞「彼」，「それら」，「それ」の出現頻度差について検討する．MT 訳で「彼」,「そ れら」,「それ」と訳されている人称代名詞が人間訳ではどのように訳されているかを調べた。そ の結果を表 11 に示す.なお,「それら」と訳されているのが人称代名詞 'they', 'their', 'them' 
ではなく，定冠詞や指示代名詞 'those’である場合があるが，この場合は集計に含めていない.

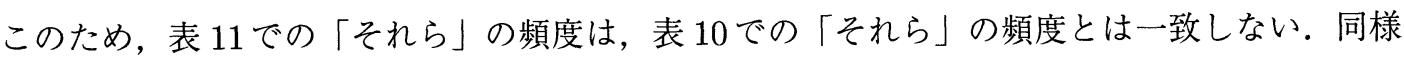
に,「それ」と訳されているのが人称代名詞 'it', 'its'ではなく，指示代名詞 'that'である場合は 集計に含めていないため,「それ」についても表 11 での頻度と表 10 での頻度は一致しない.

表 11 人間訳に打ける人称代名詞の翻訳

\begin{tabular}{|l||l|r|}
\hline MT 訳 & 人間訳 & \multicolumn{1}{|c|}{ 頻度 } \\
\hline \hline \multirow{5}{*}{ 「彼」 } & ゼロ代名詞 & $29(42.0 \%)$ \\
& 先行詞 & $19(27.5 \%)$ \\
& 「彼」 & $16(23.2 \%)$ \\
& 「自分」 & $1(1.5 \%)$ \\
& 「その」 & $1(1.5 \%)$ \\
& その他 & $3(4.3 \%)$ \\
\hline \multirow{5}{*}{$「$ 「それら」代名詞 } & $28(56.0 \%)$ \\
& ゼ先行詞 & $13(26.0 \%)$ \\
& 「自分」 & $3(6.0 \%)$ \\
& 「その」 & $3(6.0 \%)$ \\
& 「彼ら」 & $3(6.0 \%)$ \\
\hline \multirow{4}{*}{$「$ ゼれ」 } & ゼロ代名詞 & $26(74.3 \%)$ \\
& 先行詞 & $6(17.1 \%)$ \\
& 「それ」 & $2(5.7 \%)$ \\
& その他 & $1(2.9 \%)$ \\
\hline
\end{tabular}

表 11 を見ると，人間訳では，人称代名詞がゼロ代名詞化されるか先行詞に置き換えて訳され る割合が高く, 'he', 'his', 'him'の場合で $69.5 \%$, 'it', 'its'の場合で $82.0 \%$, 'they', 'their', 'them'の場合では $91.4 \%$ 占めていることが分かる.

英語では人称代名詞による照応が一般的に用いられるのに対して，日本語では，人称代名詞 による照応よりも，同一名詞の繰り返し，ゼロ代名詞，再帰代名詞などによる照応が自然である (神崎 1994).このことを反映した英日翻訳技法として，英語の人称代名詞を先行詞，ゼロ代名 詞, 再㷌代名詞に置き換えて翻訳する手法が知られている (楳垣 1975 ; 中村 1982). 今後, 人称 代名詞の翻訳に関するこのような手法を機械翻訳システムに実装していく必要があると言える.

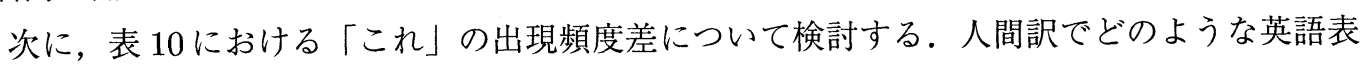
現が「これ」と訳されているのかを調べたところ，14件のうち 7 件は,「これ」に直接対応する 英語表現は存在せず，訳文で補われたものであった.「これ」の補充は，次の文 $(\mathrm{H} 7)$ のように， 一文に訳すと複雑になる文を二文に分割し，それらの間を滑らかにつなぐために行なわれてい $ろ^{9}$.

9 代名詞「これ」に類似した表現として連体詞「この」などがあるが,「この」の MT 訳における出現頻度が 5 であるのに 対して，人間訳では 55 であった。詳細な分析を行なっていないので断定できないが,「この」の頻度差も, MT 訳と人 間訳における分かりやすさの違いにつながっているのではないかと予想される。 
(E7) Leftist rebels in Colombia freed 62 government police and soldiers as part of a mass prisoner release hailed as a major boost for peace talks to end Colombia's 37 -year-old civil conflict. [2001 年 7 月 3 日]

(H7) コロンビアの左翼ゲリラが，大量の捕虜釈放の一環として，警官と兵士 62 人を 解放した。これは，37 年間にわたる内戦を終結させるための和平会議への重要な 起爆剤として歓迎されている。

（M7）コロンビアにおける左派の反逆者は，和平交渉がコロンビアの 37 年を経た民間 の対立を終えるために，メジャーな増大と認められた大規模な囚人リリースの一 部として 62 の政府警察，及び，軍人を解放した。

なお， 3.1 節で挙げた文 $(\mathrm{H} 2)$ も同様の例である.

\section{7 代名詞に関する分析}

英語の代名詞を適切に翻訳することは，(1) 代名詞を直訳すると誤った訳文や不自然な訳文 となることが多い, (2) 代名詞の出現頻度は比較的高い10,などの理由から, 英日機械翻訳にお いて重要な課題となっている (吉見 2001b). 本節では, 代名詞について 3.6 節とは別の観点か らさらに分析する。

\section{7 .1 代名詞とそれ以外の名詞の分布}

名詞全体のうちで代名詞がどの程度を占めるかを明らかにするために，人間訳と MT 訳そ れぞれにおいて，名詞全体に占める代名詞の割合を算出した。その結果を表 12 に示す。

表 12 代名詞と他の名詞の分布

\begin{tabular}{|c||r|r|}
\hline 品詞 & 代名詞 & 代名詞以外 \\
\hline \hline \multirow{2}{*}{ 人間訳 } & 66 & 3375 \\
& $1.9 \%$ & $98.1 \%$ \\
\hline \multirow{2}{*}{ MT 訳 } & 213 & 3300 \\
& $6.1 \%$ & $93.9 \%$ \\
\hline
\end{tabular}

表 12 の分布には, 統計的有意差が認められ (有意水準 $5 \%$ ), 名詞全体に占める代名詞の割 合は人間訳より MT 訳のほうが高い. 表 12 の結果は, 表 11 とも合致し, 人間訳では英語の代 名詞がゼロ代名詞化されるか先行詞に置き換えられる割合が高いことを示している.

10 我々が英字新聞を対象にして行なった調查では, 4240 文中 1845 文 $(43.5 \%)$ に人称代名詞が含まれていた。 


\subsection{2人称代名詞の訳語}

英語の人称代名詞のうち人間を指すものを直訳すると, 多くの場合, 日本語の代名詞「私」, 「我々」,「あなた」，「彼」，「彼女」，「彼ら」になる。人間訳と MT 訳におけるこれらの出現頻度 を表 13 に示す．表 13 の分布には統計的に有意な差が認められる (有意水準 $5 \%$ ).

表 13 人称代名詞の訳語の分布

\begin{tabular}{|c||r|r|r|r|r|r|}
\hline 訳語 & 私 & 我々 & あなた & 彼 & 彼女 & 彼ら \\
\hline \hline \multirow{2}{*}{ 人間訳 } & 0 & 1 & 2 & 16 & 2 & 5 \\
& $0.0 \%$ & $3.9 \%$ & $7.7 \%$ & $61.5 \%$ & $7.7 \%$ & $19.2 \%$ \\
\hline \multirow{2}{*}{$\mathrm{MT}$ 訳 } & 2 & 4 & 7 & 69 & 2 & 2 \\
& $2.3 \%$ & $4.7 \%$ & $8.1 \%$ & $80.3 \%$ & $2.3 \%$ & $2.3 \%$ \\
\hline
\end{tabular}

人間訳での出現頻度より MT 訳での出現頻度が高いもののうち,「私」,「あなた」について検 討する.「彼」については，3.6節で既に分析した。

人称代名詞 'I'が MT 訳では「私」と訳されているが人間訳ではゼロ代名詞化されている 2 件は, いずれも次の文 $(\mathrm{H} 8)$ のように, 'I'が被伝達節の主語であり, 主節の主語を指している 場合であった。

(E8) “ $P$ ve already won this one," Coach Duke said before the ceremony. [2001 年 7 月 17 日]

(H8)「「うこのゲームは勝ち取ったよ.」と，デュークコーチは式の前に言いました.

(M8)「私は，既にこれを獲得した」と，Coach 公爵は，セレモニーの前に，言った. このようなゼロ代名詞化は, 主節の主語と従属節の主語が同一の場合, 日本語では一方の主語 を省略するという原則に沿うものである.

「あなた」については，人間訳で現れていない 5 件のうち 2 件は，ゼロ代名詞化が文脈上可 能であるものであった.さらに, 別の 2 件は, 'you'が歌詞の一部でありその歌詞が原語のまま 訳文に現れているものであり，残りの 1 件は，'you'が総称的に用いられているためゼロ代名詞 化されているものであった，文脈によるゼロ代名詞化が行なわれていたのは，次のようなテキ スト (E9) における第二文の'you'である。なお，テキスト (E9) の第一文は，無作為抽出した 標本には含まれていない.

(E9) Is your last name Dunlop? If so, you're eligible for a big payoff. [2001 年 12 月 19 日]

(H9) もしかして, あなたの苗字はダンロップさんではないですか. もしそうなら, 大 金をもらう資格があります。

(M9) あなたの姓は，ダンロップであるか？もしそうであるならば，あなたは，大きな 
利益に適格である.

現在市販されている機械翻訳システムでは一文を越える範囲での処理はほとんど行なわれて いないが，このようなゼロ代名詞化を実現するためには，文間照応の解析などを実装していく 必要がある。

\subsection{3一文に含まれる人称代名詞の数}

人間訳と MT 訳とで，一文中に含まれる代名詞の数に違いがあるかどうかを明らかにする ために，代名詞を $n$ 個含む文の分布を調べた。その結果を表 14 に示す。表 14 の分布には，統 計的な有意差は認められない (有意水準 $5 \%$ ).

表 14 人称代名詞の訳語を $n$ 個含む文の分布

\begin{tabular}{|c||r|r|r|r|}
\hline$n$ & \multicolumn{1}{|c|}{1} & \multicolumn{1}{c|}{2} & \multicolumn{1}{c|}{3} & \multicolumn{1}{c|}{4} \\
\hline \hline \multirow{2}{*}{ 人間訳 } & 25 & 1 & 0 & 0 \\
& $96.2 \%$ & $3.8 \%$ & $0.0 \%$ & $0.0 \%$ \\
\hline \multirow{2}{*}{$\mathrm{MT}$ 訳 } & 64 & 9 & 0 & 1 \\
& $86.5 \%$ & $12.1 \%$ & $0.0 \%$ & $1.4 \%$ \\
\hline
\end{tabular}

表 14 を見ると, 人間訳では一文に最大で二つしか人称代名詞が含まれないのに対して, MT 訳では四つも含む文がある，MT 訳で人称代名詞を四つ含むのは次の文 (E10) に対する文 (M10) である。

(E10) In a repeat of previous run-ins between the pair, May then turned off Milosevic's microphone, told him he would have his chance to make his case during the trial and closed the hearing. [2002 年 1 月 11 日]

(H10) 前回交わされた言い合いの繰り返しになり，メイ氏はミロシェビッチ氏のマイク ロホンのスイッチを切り，ミロシェビッチ氏に対し公判中に自己弁護できる機会 があると告げ審問手続きを終了させた。

(M10) ペアの間の前のロげんかの反復において, 5 月は, それからミロセビッチのマイ クロホンをオフにし，彼にトライアルの間に彼のケースを作る彼のチャンスがあ るであろう，と彼に告げ，そして，ヒアリングを閉じた。

文 (M10) には, 訳語選択において不適切な点がいくつかあるので，人称代名詞以外の部分 を人間訳と同じにして，比較してみる．次の文 $(\mathrm{J} 11)$ は人称代名詞以外の部分を人間訳に置き 換えたものである。なお，'make his case'の訳語を慣用句として「自己弁護する」と辞書に登 録しておけば, 'his'は訳出されないものと仮定した.

(J11) 前回交わされた言い合いの繰り返しになり，メイ氏はミロシェビッチ氏のマイク 
ロホンのスイッチを切り，彼に対し公判中に自己弁護できる彼の機会が彼にある と告げ審問手続きを終了させた。

文 (H10) では, 'him'は「ミロシェビッチ氏」と訳され, 'he'と 'his'はゼロ代名詞化されて いる。これに対して，文(J11) では，'him’を「ミロシェビッチ氏」ではなく「彼」としている のは許容できるが，'he'と'his'を「彼」と訳しているのは不自然に感じられる.

\section{4 おわりに}

本稿では，人間訳と MT 訳にどのような違いがあるのかを明らかにするための第一歩とし て, 英文一文に対する訳文の数, 訳文の長さ, 訳文に含まれる連体修飾節の数の違いを計量分 析し，さらに，動詞，名詞，代名詞について人間訳と MT 訳を比較した。その結果，次のよう な点が明らかになった。

人間訳に比べ MT 訳には，英文一文が複数の訳文に分割されにくい傾向がある．MT 訳では分割されないが人間訳では分割される箇所として，関係代名詞や前置詞などが 目立つ，関係代名詞での分割では，関係代名詞が先行詞に置き換えられることが多 い. 前置詞での分割では，前置詞句を日本語に翻訳したとき，完全な文になるように 工夫が施されている．分割した文の間を滑らかにつなぐために照応表現が補われるこ とがある。

（2）訳文の長さ (文節数) の分布に統計的有意差が認められる.

(3) 用言の連用形と連体形の分布に有意差が認められ, MT 訳のほうが人間訳よりも複雑 な構造をした文が多いことが示唆される.

（4）体言と用言の分布に有意差は認められない.

（5）動詞に関するMT 訳の主な課題としては，英語の「する」的表現を日本語で好まれる 「なる」的表現に翻訳すること，ある内容を言語形式化する際の表現手段の選択肢の 一つとして機能動詞表現を考慮に入れることなどが挙げられる.

（6）名詞と代名詞に関しては，複雑な関係代名詞節を連体修飾節に翻訳しないようにする 処理，人称代名詞をゼロ代名詞化するかあるいは先行詞に置き換える処理などを実現 することが課題である.

人間訳と MT 訳の計量的比較分析は, 機械翻訳システムが抱える問題点について改めて考 え直したり，これまで見逃されていた問題点を見つけたりする上で有用である. 今後，構文レ ベルでの分析を行なっていく予定である.

謝辞 本稿の改善に非常に有益なコメントを頂いた査読者の方, 内山将夫氏 (通信総合研究 所), 小谷克則氏 (関西外国語大学) に感謝いたします. 


\section{参考文献}

安西徹雄 (1982). 翻訳英文法一訳し方のルール-. バベル双書. 日本翻訳家養成センター, 東京. 安西徹雄 (1983). 英語の発想. 講談社, 東京.

Darwin, M. (2001). "Trial and Error: An Evaluation Project on Japanese \langle\rangle English MT

Output Quality." In Proceedings of the 8th Machine Translation Summit, pp. 77-82.

蓮見陽子 (1991). “同一情報に基づく文章表現の異同についての分析.”計量国語学, 18 (3), pp. 136-144.

波多野完治 (1965). 文章心理学〈新稿〉. 文章心理学大系 1 . 大日本図書, 東京.

堀川直義 (1979). “文体比較法の一つの試み.”山口仲美（編）, 文章・文体, 論集 日本語研究 8 ,

pp. 112-117. 有精堂, 東京.

池上嘉彦 (1981). 「する」と「なる」の言語学一言語と文化のタイポロジーへの試論一. 大修 館書店, 東京.

金明哲，樺島忠夫，村上征勝 (1993). “手書きとワープロによる文章の計量分析.”計量国語学, 19 (3), pp. 133-145.

樺島忠夫 (1963). “文体の語学的研究.” 時枝誠記, 遠藤嘉基, 森岡健二, 永野賢, 宮地裕, 市川孝

(編)，文章と文体, 講座 現代語 5, pp. 221-237. 明治書院, 東京.

亀井忠一 (1994). 頭からの翻訳法. 信山社, 東京.

神崎高明 (1994). 日英語代名詞の研究. 研究社出版, 東京.

加藤輝政, 小川清, 佐良木昌 (1997). “英語複文の構文解析と編集、その論理と方法.” 研究報

告 NL120-10, 情報処理学会.

近藤正臣 (1992). “英語における後置修飾節の邦訳一同時通訳の処理法より学ぶ—. 大東文化

大学紀要〈人文科学〉, 30, pp. 277-294.

森岡健二 (1988). 文体と表現. 現代語研究シリーズ 5. 明治書院, 東京.

村木新次郎 (1991). 日本語動詞の諸相. ひつじ書房, 埼玉.

村田真樹, 内元清貴, 馬青, 井佐原均 (1999). “日本語文と英語文における統語構造認識とマジ

カルナンバー $7 \pm 2 . ”$ 自然言語処理, 6 (7), pp. 61-73.

Nagao, M., Tsujii, J., and Nakamura, J. (1985). "The Japanese Government Project for Machine Translation." In Slocum, J. (Ed.), Machine Translation Systems, pp. 141-186. Cambridge University Press, Cambridge.

中村保男 (1982). 翻訳の秘訣一理論と実践—. 新潮選書. 新潮社, 東京.

Niessen, S., Och, F., Leusch, G., and Ney, H. (2000). "An Evaluation Tool for Machine Translation: Fast Evaluation for MT Research." In Proceedings of the 2nd International Conference on Language Resources and Evaluation (LREC2000), pp. 39-45.

野上優, 藤田篤, 乾健太郎 (2000). “文分割による連体修飾節の言い換え.”言語処理学会第 6 
回年次大会発表論文集, pp. 215-218.

Papineni, K., Roukos, S., Ward, T., and Zhu, W. (2002). "BLEU: A Method for Automatic

Evaluation of Machine Translation." In Proceedings of the 40th Annual Meeting of the Association for Computational Linguistics (ACL2002), pp. 311-318.

佐良木昌 (2001). “機械翻訳の訳文改善一英文の名詞句構造・後置修飾構造の訳出方法一.”言 語処理学会第 7 回年次大会ワークショップ論文集, pp. 41-44.

菅谷史昭, 竹澤寿幸, 横尾昭男, 山本誠一 (2001). “音声翻訳システムと人間との比較による音 声翻訳能力評価手法の提案.” 電子情報通信学会論文誌, J84-D-II (11), pp. 2362-2370.

楳垣実 (1975). 日英比較表現論. 大修館書店, 東京.

山口仲美 (1979). 文章・文体. 論集 日本語研究 8. 有精堂, 東京.

柳父章 (1979). 比較日本語論. バベル・プレス, 東京.

吉見毅彦 (2001a). “英日機械翻訳における自然な和文生成のための英語名詞句の書き換え.”自

然言語処理, 8 (4), pp. 55-70.

吉見毅彦 (2001b). “英日機械翻訳における代名詞翻訳の改良.”自然言語処理, $8(3)$, pp. 87-106.

\section{略歴}

吉見毅彦: 1987 年電気通信大学大学院計算機科学専攻修士課程修了. 1999 年 神戸大学大学院自然科学研究科博士課程修了. (財) 計量計画研究所 (非常勤), シャープ (株) を経て, 2003 年より龍谷大学理工学部情報メディア学科勤務.

(2003 年 1 月 15 日 受付)

(2003 年 3 月 16 日 再受付)

$(2003$ 年 4 月 20 日採録) 